\title{
“Os bondes já estão parando" : uma reflexão sobre as greves de abril de 1945 em Porto Alegre
}

Fernando Cauduro Pureza

Resumo: O presente artigo visa discutir as greves de abril de 1945 sob a seguinte perspectiva: diante da intensa repressão ao movimento operário ao longo dos anos do Estado Novo e da constante vigília sindical correspondente à legislação trabalhista do período, quais foram as formas específicas de luta que permitiram aos operários porto-alegrenses se rearticular na organização dessas greves? Tal questionamento visa elucidar algumas condições do movimento, especialmente retomando as experiências com que os agentes se defrontaram nos últimos anos do regime de Vargas, concomitantes com a participação do Brasil na Segunda Guerra Mundial.

Palavras-chave: Greves; movimento operário; Porto Alegre.

Abstract: The following article pretends to discuss the strikes of april 1945 in the following perspective: facing the strong repression against the labor movement in the Estado Novo years and facing the constant watch of the trade-unions corresponding the labor laws of the period, which were the specific forms of struggle that allowed the Porto Alegre working-men to rearticulate themselves in the organization of this strikes? This question tries to elucidate some of the conditions of the movement, specially retaking the experiences that the agents faced themselves in the last years of Vargas regime, concurrent to the Brazilian participation in the Second World War.

Keywords: Strikes; labor movement; Porto Alegre.

\section{INTRODUÇÃO}

Avaliar as greves de abril de 1945 em Porto Alegre exige uma reflexão um pouco cautelosa. Antes de adotar a ideia de um operariado desprendido das amarras da repressão política e da propaganda do Estado Novo, talvez seja importante analisar as formas históricas pelas quais o movimento pôde se rearticular de formas mais autônomas, contrastando com o controle sindical que lhe era imposto. Alexandre Fortes, em artigo recente sobre o movimento operário porto-alegrense na conjuntura de greves de 19291930, afirma que:

Num processo de acúmulo que se estendeu por uma geração e foi concluído quando amadureceu uma nova configuração de classe, os trabalhadores conquistaram a possibilidade de lidar com a lei não apenas enquanto ordem

${ }^{*}$ Mestre em História pela UFRGS 
pública inibidora pela sua capacidade de manifestação, temperada eventualmente pela ação magnânima da autoridade protecionista, mas também como reconhecimento, mesmo que a princípio pouco efetivo, de sua titularidade a direitos sociais ${ }^{1}$.

Contudo, esse processo de acúmulo se demonstra bastante fluido, com retrocessos e avanços que estão presentes ao longo do Estado Novo. Somado a esse quadro, não se pode esquecer o fato de que de 1942 a 1945 os trabalhadores são convocados para ingressar na "batalha da produção" como "soldados-operários", numa exigência ainda maior pelo aumento produtivo para que o Brasil vencesse a guerra contra os países do Eixo. Porém, cientes de que Estado e burguesia aproveitaram também o momento para intensificar o controle sobre a força de trabalho, os operários demonstraram que situações como o aumento da jornada de trabalho ou a escassez de gêneros alimentícios no mercado de Porto Alegre revelavam uma espécie de desprezo a esses "soldados-operários" ${ }^{2}$. A mesma lei que amparava também poderia ser considerada lenta ou ineficiente para os próprios trabalhadores, mesmo estando eles cada vez mais próximos de um estatuto de cidadania ${ }^{3}$. É diante desse momento específico que uma semana em abril ganha tamanho destaque, pois é na segunda semana desse mês que o movimento operário porto-alegrense saiu às ruas para enfrentar tanto a repressão política da ditadura como o patronato.

Contudo, essa ação necessita ser abordada com maiores cuidados. É certo que a greve é um instrumento histórico do movimento operário desde suas próprias origens. $\mathrm{O}$ economista Karl Polanyi, nos anos 1940, definiu-a como o instrumento de negociação por excelência por parte dos trabalhadores, pois é através dessa forma de associação que eles

\footnotetext{
${ }^{1}$ FORTES, Alexandre. Os direitos, a lei e a ordem: greves e mobilizações gerais na Porto Alegre da Primeira República. IN: LARA, Silvia Hunold. MENDONÇA, Joseli Maria Nunes (org.). Direitos e Justiça no Brasil. Campinas. Editora Unicamp, 2006, p. 374.

${ }^{2}$ Sobre a questão da escassez de gêneros alimentícios nos lares operários durante a Segunda Guerra Mundial, ver: PUREZA, Fernando Cauduro. "Apertar os cintos": trabalhadores e escassez em Porto Alegre (1942-1945). In: Revista História Social - Revista dos Pós-graduandos em História da Unicamp. № 14/15. Campinas. Ed. UNICAMP, 2008, p. 175-195.

${ }^{3}$ Quanto a esse ponto, o artigo "Direitos por lei, ou leis por direito", da historiadora Broadwyn Fischer, faz um contraponto à ideia de Ângela de Castro Gomes, que avalia o período de 1942 como ponto-chave para compreender que o projeto trabalhista de Vargas construiu uma noção de cidadania apoiada na identidade de trabalhador. Para Fischer, contudo, essa identidade de trabalhador apoiava-se num estatuto jurídico a que poucos tinham acesso, devido especialmente à burocracia existente para adquirir documentos essenciais, como carteira de trabalho, por exemplo. Para mais, ver: GOMES, Ângela de Castro. Cidadania e direitos do trabalho. Rio de Janeiro. Ed. Jorge Zahar, 2002. Ver também: FISCHER, Broadwyn. Direitos por lei, ou leis por direito? Pobreza e ambigüidade legal no Estado Novo. In: LARA. MENDONÇA.(org.). Op. cit.
} 
poderiam negociar questões como o seu próprio salário e a jornada de trabalho ${ }^{4}$. Porém, durante o Estado Novo, como já foi observado, a greve fora tornada ilegal e essa alternativa de luta se tornou quase impossível ao movimento operário ${ }^{5}$. Ainda que permitindo a organização dos trabalhadores através da sindicalização de formato corporativista, a restrição da greve era essencial ao projeto político de "cooperação" entre trabalho e capital.

Mesmo defendendo tal organização operária em seus órgãos de representação classista, o projeto trabalhista não considerava, em seus primórdios, o direito de greve. Luiz Werneck Vianna foi um dos autores que melhor apresentou os problemas que eram colocados pela repressão política e pelo controle do trabalho no período. Segundo ele, a Lei de Segurança Nacional, de abril de 1935, era extremamente restritiva à greve de qualquer funcionário público, e para trabalhadores do setor de abastecimento ela só era permitida por "motivos pertinentes às condições de seu trabalho" ${ }^{6}$. A legislação de 1935 abriu espaço para que, em 1937, a nova Constituição afirmasse ser a greve um recurso antissocial. Dessa forma, o argumento de Vianna sustenta que capital e trabalho defrontavam-se com um Estado que estaria se colocando acima dos interesses particulares, chamando as partes negociadoras "ao cumprimento do bem comum"7

O "bem comum", como se sabe, era extremamente limitador das capacidades de negociação por parte dos trabalhadores. Nas palavras do autor:

\begin{abstract}
A linguagem corporativa reduziu-se aos pronunciamentos dos dirigentes políticos do Estado, e até isto por um lapso de tempo breve. Os institutos corporativos, contra a intenção visível do legislador, foram esvaziados de sua filosofia "colaboracionista", convertendo-se em instrumentos de crua dominação de classes. Na prática, agia o Capital num meio que acabava por ser calidamente liberal, protegido por um discurso que elevava a otimização dos seus lucros a uma função do poder público ${ }^{8}$.
\end{abstract}

Portanto, se por um lado pode-se afirmar que a lei tenta tornar uma determinada relação de dominação de classes como neutra ou inexistente, por outro ela é, na sua aplicação, parcial. No caso, como afirma Vianna, ela permitia ao capital um espaço de

\footnotetext{
${ }^{4}$ POLANYI, Karl. A grande transformação: as origens de nossa época. Rio de Janeiro. Ed. Campus, 2000, p. 180181.

${ }^{5}$ Entretanto, há registro de greves curtas e localizadas ao longo do Estado Novo e mesmo durante a guerra, especialmente na cidade de São Paulo. Ver: COSTA, Hélio da. Em busca da memória: comissão de fábrica, partido e sindicato. São Paulo. Ed. Scritta, 1995. Capítulo 1: A luta dos trabalhadores no final do Estado Novo, p. 11-52.

${ }^{6}$ VIANNA, Luiz Werneck. Liberalismo e sindicato no Brasil. São Paulo. Ed. Paz e Terra, 1989, p. 200.

${ }^{7}$ Ibid., p. 218.

${ }^{8}$ Ibid., p. 222.
} 
atuação maior, ainda que restrito aos próprios limites impostos pelo governo. É nesse conflito entre o que a legislação pretende ser e o que ela realmente se revela que os trabalhadores podiam atuar tanto pelas vias legais, quanto buscando confrontar esse campo com ações ilegais, como é o caso das greves.

Se os trabalhadores poderiam "recriar suas armas" e fazer da greve novamente um direito, é preciso entender como foi feita a recuperação dessa tradição do movimento operário no período. O descontentamento já existia, e grupos organizados, como os comunistas, já consideravam que deveria haver uma forma de canalizar os problemas da economia doméstica dos trabalhadores para a reorganização política do partido e para sua legitimação como força antifascista.

No entanto, se os comunistas eram capazes de se organizar - ainda que de forma muito restrita e sob a intensa vigilância do DOPS -, não seria possível pensar que existiam formas de organização entre outros grupos políticos no interior da classe trabalhadora? A situação do período propiciava até mesmo que se pensasse novamente em mecanismos de organização menos formais. Em fevereiro de 1945 Vargas já acenava com a liberalização política do regime, provavelmente diante de pressões que se colocavam pelo próprio esforço de guerra em prol das "democracias ocidentais". A possibilidade do surgimento de oposição à ditadura de Vargas e a suspensão da lei de censura no mesmo mês garantiam um clima propício para a reorganização política de grupos civis, inclusive os trabalhadores. Somado a esses movimentos, o Brasil participara da Conferência de Chapultepec, em fevereiro/março de 1945, ratificando as decisões que "consagravam direitos sociais, entre os quais o reconhecimento do direito de associação dos trabalhadores, do contrato coletivo e do direito de greve." Anunciavam-se, assim, as mudanças constitucionais de 1946, quando a greve deixaria de ser um delito para se tornar um direito ${ }^{9}$.

\section{O MOVIMENTO GREVISTA}

É válido ressaltar que em algumas cidades brasileiras já havia movimentações por parte dos operários antes mesmo da gradual abertura política do regime do Estado Novo.

\footnotetext{
${ }^{9}$ MATTOS, Marcelo Badaró (coord.). Greves e repressão policial ao sindicalismo carioca: 1945-1964. Rio de Janeiro. Ed. FAPERJ, 2003, p. 81.
} 
Em São Paulo, por exemplo, Hélio da Costa analisou algumas das movimentações dos operários durante os anos da guerra. Em 1942 houve uma greve na periferia de São Paulo, em uma usina que atrasara o salário de seus empregados. Em 1943 e 1944, atos semelhantes se repetiram, com paralisações e abaixo-assinados de operários que protestavam contra suas condições de trabalho, ou que exigiam um reajuste salarial conforme seu custo de vida, ou mesmo que exigiam apenas o que lhes era legalmente garantido, como o "abono de Natal" em dinheiro e não em espécie ${ }^{10}$. Porém, tais iniciativas passaram por fora dos sindicatos de classe, o que colocava esses trabalhadores em risco. Em um depoimento coletado pelo historiador, um dos operários do período, Ronaldo Fratti, fala sobre a greve geral que teria ocorrido em 1944:

\begin{abstract}
Houve uma pressão muito grande pelo décimo terceiro salário, por exemplo, em Santo André. Acabou tendo greve geral dos químicos e têxteis, que eram as categorias que mais precisavam disso, tinham salários mais baixos [...]; houve 430 prisões, não cabia nas prisões, então encheram o pátio ${ }^{11}$.
\end{abstract}

Entretanto, mesmo com movimentações políticas nos anos anteriores, Hélio da Costa afirma que as greves que ocorreram em abril de 1945 em São Paulo foram diferentes das anteriores. Possivelmente por terem sido amplamente difundidas, mas principalmente pelo clima político do início do ano de 1945. Com a guerra na Europa prestes a terminar e com o regime Vargas defendendo o enfrentamento contra o nazi-fascismo em nome das democracias ocidentais, a situação era realmente diferenciada. O "esforço de guerra" não era mais argumento suficiente para sufocar as tentativas de organização do movimento operário e mesmo o apelo patriótico, que membros do governo e líderes sindicais poderiam fazer, tinha limites ${ }^{12}$.

Mas, ao que tudo indica, São Paulo não era a única cidade onde havia agitações por parte dos operários durante os anos de esforço de guerra. Antônio de Oliveira e Eulália Maria Lahmeyer Lobo afirmam que em 1944, na cidade do Rio de Janeiro, já havia uma retomada dos comunistas nos sindicatos, procurando organizar campanhas salariais entre os

\footnotetext{
${ }^{10}$ Sobre isso, Hélio da Costa afirma que as indústrias Pirelli garantiam esse abono através apenas da boa vontade do empregador, podendo variar de uma lata de marmelada até mesmo a uma cesta de alimentos. Ver COSTA, Hélio da. op. cit., p. 12-15.

11 Ibidem, p. 15.

${ }^{12}$ Hélio da Costa, em entrevista a Armando Mazzo, relata uma situação em que o coordenador do esforço de guerra fora visitar o Sindicato dos Metalúrgicos de São Paulo e criticar a greve da categoria. Enaltecendo o "esforço de guerra" para a defesa do Exército brasileiro, o coordenador foi interrompido pelas lideranças sindicais que afirmavam que ele deveria usar o adjetivo "glorioso" antes de se referir ao Exército brasileiro para poder criticar os trabalhadores. Ibidem, p. 20.
} 
trabalhadores ${ }^{13}$. Ainda que o estudo não aponte mobilizações grevistas, ou mesmo abaixoassinados, ele parece confluir com a ideia que Hélio da Costa sugere para o caso de São Paulo: diante da dificuldade de organizar os trabalhadores para formas mais diretas de ação política no enfrentamento com o patronato, restava a eles organizarem-se por fora dos sindicatos, em comitês ou células.

No Rio Grande do Sul também há casos de agitações operárias antes de abril de 1945, como pode se ver na categoria dos mineiros da região de São Jerônimo e Butiá. Na tese de doutorado de Gláucia Vieira Ramos Konrad, a autora revela que desde 1934 essa categoria fora bastante atuante e estava constantemente mobilizada para discutir suas condições de trabalho e os seus salários, inclusive exigindo o cumprimento da legislação trabalhista conforme as leis foram se consolidando ${ }^{14}$. Em 1943 houve intervenção militar em muitas minas da região, provavelmente para lidar com os protestos de mineiros que eram acusados do crime de "deserção" pelo Consórcio Administrador de Empresas de Mineração ${ }^{15}$. Além disso, Alexandre Fortes cita em sua pesquisa sobre o Quarto Distrito de Porto Alegre durante a Era Vargas o caso de uma greve dos metalúrgicos em 1944, retirada de uma entrevista realizada por Maria Elizabeth Grimberg, em 1982, com o líder sindical José César Mesquita.

No entanto, essa greve carece de documentação mais sólida para ser analisada. Segundo Fortes, no final de novembro de 1944 os metalúrgicos desencadearam uma paralisação que durara 15 dias, reivindicando um aumento salarial de $1 \$ 000$ por dia ${ }^{16}$. Tal valor seria equivalente a $\mathrm{Cr} \$ 1,00$ por dia, o que somado ao salário-mínimo de $\mathrm{Cr} \$ 380,00$ teria um acréscimo de mais de $\mathrm{Cr} \$ 24,00$. O problema, no entanto, é que não há outros documentos do Sindicato dos Trabalhadores da Indústria Metalúrgica, Mecânica e de Materiais Elétricos que comprovem a existência dessa paralisação. Os escassos materiais oficiais do sindicato sobre esse período revelam apenas que José César Mesquita encabeçou a diretoria sindical eleita em setembro de 1944, mas que não tomou posse até pelo menos

\footnotetext{
${ }^{13}$ LOBO, Eulália Maria Lahmeyer e OLIVEIRA, Antônio. O Estado Novo e o sindicato corporativista (1937-1945). In: LOBO, Eulália Maria Lahmeyer (coord.). Rio de Janeiro operário: natureza do Estado, conjuntura econômica, condições de vida e consciência de classe. Rio de Janeiro. Access Editora, 1992, p. 180-181.

${ }^{14}$ KONRAD, Gláucia Vieira Ramos. Os trabalhadores e o Estado Novo no Rio Grande do Sul: um retrato da sociedade e do mundo do trabalho (1937-1945). Campinas: Unicamp, 2006 (Tese de Doutorado). p. 137-143.

${ }^{15}$ Agradeço à colega Clarice Gontarski Esperança pelas referências à intervenção da Justiça Militar na região carbonífera do Rio Grande do Sul durante o período do "esforço de guerra".

${ }^{16}$ FORTES, Alexandre. Nós do quarto distrito: a classe trabalhadora porto-alegrense e a Era Vargas. Caxias do Sul. EDUCS, 2004, p. 377.
} 
$1945^{17}$. Nas suas memórias, o militante comunista Eloy Martins tampouco faz referência a essa greve de 1944. Sem outros materiais que informem sobre ela, não há como saber sua duração e seu impacto. Entretanto, o silêncio de materiais do próprio sindicato pode revelar uma semelhança da situação de Porto Alegre com a de São Paulo, levantando a hipótese de que talvez essa paralisação tenha ocorrido à margem da entidade de classe.

Mas como se davam essas formas de organização que, aparentemente, teriam de ser tão subterrâneas? Diz-se aparentemente, é claro, pela falta de documentos sobre elas. Geralmente a documentação encontrada limita-se às memórias de militantes, que organizaram células clandestinas do PCB, ou comissões de fábrica por fora dos sindicatos. De certa forma o caráter "subterrâneo" faz parte das narrativas produzidas sobre elas num contexto repressivo, mas será que elas eram efetivamente tão sutis assim?

Pode-se tomar como exemplo a greve dos ferroviários gaúchos, que começara no dia 5 de abril, revelando uma forma de organização bastante interessante, baseada no telégrafo da Viação Férrea do Rio Grande do Sul. Ao que tudo indica, essa paralisação teve origem na cidade de Santa Maria na madrugada e rapidamente espalhou-se para Porto Alegre e Bagé pela movimentação secreta do sistema de telégrafos dos ferroviários. Dessa forma, a greve poderia se tornar geral entre todos os trabalhadores da categoria, o que realmente ocorreu $^{18}$.

No entanto, na mesma notícia o Correio do Povo divulga que "a greve surgiu de um movimento espontâneo entre a classe, já que havia reivindicado aumento de vencimentos sem ser atendida em suas pretensões". Era verdade que não faltavam notícias sobre os problemas que os ferroviários enfrentavam com o custo de vida e a excessiva jornada de trabalho. Mas, mesmo assim, um sistema tão eficiente de comunicação secreta, que conseguiu conectar os principais centros de articulação da categoria para a greve, faz com que o historiador se coloque um tanto quanto cético sobre a "espontaneidade" do movimento. A partir das notícias da imprensa, por outro lado, podem-se deduzir duas

\footnotetext{
${ }^{17}$ Diretorias do Sindicato dos Trabalhadores das Indústrias Metalúrgicas, Mecânicas e de Material Elétrico de Porto Alegre. Acervo do Sindicato dos Metalúrgicos de Porto Alegre. Porto Alegre, 2 de julho de 1971. A cartilha "60 anos na Luta", produzida para comemorar o sexagésimo aniversário do sindicato, tampouco faz referência a essa greve, mesmo que entre os consultados estejam nomes como o de Júlio Cézar de Mesquita e o de Eloy Martins.

${ }^{18}$ Essas e as demais informações remetem à notícia: "Paralisado, desde a manhã de ontem, todo o tráfego ferroviário do Estado". Correio do Povo, Porto Alegre, 6/4/1945, p. 8.
} 
importantes influências que marcaram a erupção da greve dos ferroviários: a greve das docas de Santos e a passeata pela anistia dos presos políticos, um dia antes.

No primeiro caso, o Correio afirma em poucas linhas que "essa parede encontrou eco e ganhou vulto ao irromper, com resultados práticos, a greve nas docas do porto de Santos". De fato, a greve de Santos irrompera no dia 2 de abril e fora noticiada pela imprensa gaúcha alguns dias depois, enaltecendo os 4 mil trabalhadores portuários que cruzaram os braços de forma "ordeira"19. A greve de Santos sem dúvida foi uma das mais fortes agitações da classe trabalhadora naquele mês. Entre paralisações e negociações, mais de um mês de greve se passou. Os movimentos nas docas foram marcados por disputas com o sindicato - que não autorizava a greve - assim como pela intensa repressão tanto da Superintendência da Companhia como do próprio DOPS-SP. Sem dúvida, o fôlego inicial do movimento operário nos portos de Santos se tornou exemplar para muitos trabalhadores do país e os ferroviários gaúchos não foram exceção. Porém, como demonstra Fernando Teixeira da Silva na sua pesquisa sobre os trabalhadores portuários de Santos de 1937 a 1960, muitos dos grevistas eram membros do PCB, o que coloca em discussão o suposto "apartidarismo" do movimento, assim como a sua espontaneidade ${ }^{20}$.

Essa greve teve grande influência no movimento dos ferroviários do Rio Grande do Sul. Cabe, então, perguntar também qual teria sido a influência do PCB. Tal tema é complexo, pois como será visto mais adiante, existem indícios de que, de fato, os comunistas tinham um peso político forte entre a categoria. Mas até que ponto a influência do partido ajuda a explicar a greve? Num primeiro momento, deve-se lembrar que no dia anterior à paralisação dos ferroviários, 4 de abril, uma passeata pela anistia dos presos políticos fora organizada na capital gaúcha. Lá, a bandeira da União Soviética aparecia logo à frente da manifestação, sendo flagrada pelas fotos dos jornais da cidade. Segundo o Diário de Notícias, a primeira bandeira soviética a aparecer no Rio Grande do Sul desde o Estado Novo fora confeccionada por alguns notórios membros do PCB, como Gilda Marinho e Décio Freitas. Ainda que não se tratasse de militantes operários, certamente identificava a tentativa do

\footnotetext{
${ }^{19}$ A imagem positiva da greve, no entanto, deve ser avaliada com cautela. Vindo do Diário de Notícias, empresa dos Diários Associados, de Assis Chateaubriand, ela expressava mais esse suposto apoio na intenção de fazer oposição ao regime Vargas do que por solidariedade às pautas dos próprios trabalhadores marítimos. Ver: "Em greve pacífica justificada com um quadro de necessidades, mais de quatro mil operários da Cia. Docas de Santos". Diário de Notícias, Porto Alegre, 5/4/1945, p. 3.

${ }^{20}$ SILVA, Fernando Teixeira. A carga e a culpa. São Paulo: Hucitec, 1995, p. 88-97.
} 
PCB de fazer-se presente na sociedade civil. Com a imprensa gaúcha tomando a passeata como marco da democracia que estava "nascendo" no Brasil, é possível que esse mesmo pensamento existisse entre os operários, que poderiam constatar um clima mais favorável para a ação política ${ }^{21}$.

Entretanto, apesar desse momento de exposição dos comunistas na grande imprensa, os principais organizadores da greve negaram a participação de elementos estranhos no movimento. No dia 6 de abril, segundo dia de greve, em uma assembleia na cidade de Santa Maria, os principais líderes operários fizeram declarações afirmando o caráter "não-político" do movimento, atribuído especialmente por Giácomo Silva ${ }^{22}$. De fato, não faltaram ferroviários afirmando que não havia "infiltrados" e muito menos "provocadores" no movimento, inclusive com a comissão dos grevistas estabelecendo restrições ao consumo de álcool. Porém, pode-se entender que o principal temor por parte dos militantes era o de que a greve fosse concebida como atividade comunista, o que explicaria a necessidade de tornar o movimento "espontâneo" em seus discursos. Tal temor é esclarecido pelo telegrama do interventor federal no Rio Grande do Sul, o tenente coronel Ernesto Dornelles:

\begin{abstract}
Em face do desenvolvimento que vem tendo, o movimento grevista deixou de se revestir da forma de reivindicação para transformar-se em motivo de perturbação da ordem e ameaça à segurança social, caso em que o governo tomará medidas radicais para restabelecer a tranqüilidade pública, responsabilizando todos os agitadores. Deveis advertir os cabeças do movimento aí sobre o possível agravamento que uma conduta irrefletida trará à situação e a margem à exploração política, que estão dando aos agitadores, com prejuízo para as reivindicações dos operários. Qualquer anormalidade provocada com esses intuitos será rigorosamente apurada a fim de que os culpados sejam devidamente punidos.
\end{abstract}

O tom ameaçador do telegrama não soava como mera retórica política aos operários, que já conheciam o sistema de repressão do Estado Novo para saber que não se tratava de blefe. Logo, evitar que "provocadores" e "agitadores" fossem encontrados no movimento não significava excluir comunistas e demais grupos políticos do movimento, mas sim impedir que fossem identificados com a classe. Dito de outra forma, o recurso retórico da defesa da espontaneidade era fundamental para a própria sobrevivência do movimento. De fato, quando a greve já estava terminada, no dia 7, por iniciativa das negociações do diretor da

\footnotetext{
21 "Em perfeita ordem, o povo de Porto Alegre reuniu-se num vibrante comício pró-anistia". Correio do Povo, Porto Alegre, 5/4/1945, p. 8. Ver também: “Tem sua história essa bandeira soviética". Diário de Notícias, Porto Alegre, 5/4/1945, p. 10.

22 “Em Santa Maria o diretor da Viação Férrea". Correio do Povo, Porto Alegre, 7/4/1945, p. 5 e 8.
} 
companhia, o tenente-coronel José Diogo Brochado da Rocha, as lideranças grevistas chegaram a pedir que os ferroviários não participassem dos comícios pró-anistia encabeçados pelo $\mathrm{PCB}^{23}$. Ou seja, no caso gaúcho, é muito provável que o "espontaneísmo" da greve, ou a ausência de ligação com o PCB, fosse uma estratégia para enfrentar a repressão que se verificava sobre o partido e seus membros.

Os ferroviários alcançaram muitas de suas reivindicações, tendo a questão salarial envolvido boa parte das negociações de Brochado da Rocha com a Viação Férrea. Algumas das suas principais conquistas foram o atendimento às pretensões de ter uma definição jurídica da categoria, o abono familiar de funcionário público e a garantia de que não haveria retaliação ao movimento, sendo essa particularmente importante diante das ameaças que pairavam sobre eles, vindas do próprio interventor federal. Essas ameaças punham em xeque a retórica de greves apolíticas, o que deve levar o pesquisador a questionar aparentes evidências como as que parecem apontar para o "espontaneísmo" do movimento.

Um bom exemplo dos riscos de uma leitura excessivamente crédula das fontes pode ser visto na greve dos transviários de Porto Alegre, que certamente recebeu a influência da greve dos ferroviários. No dia 5 de abril de 1945, quando começou o movimento grevista na capital gaúcha, os funcionários da Cia. Carris Porto-Alegrense de Transportes Urbanos demonstraram um diferente método de articulação, segundo a matéria do jornal Correio do Povo. Cerca de 1.100 operários da empresa pararam o serviço às 17 horas e marcharam em direção à sede do jornal, posando para uma foto em que apareciam inúmeros braços levantados com o número 4 simbolizado nos dedos (referindo-se aos $40 \%$ de aumento salarial que reivindicavam). O Correio explicava a situação da seguinte forma:

Desde o meio-dia que a cidade foi sacudida com o boato da greve. Pela manhã, tal
atitude fora já tomada pelos funcionários da Viação Férrea, numa "parede" de
extensão estadual que paralisou todo o tráfego ferroviário. A repercussão da greve
ferroviária tinha de ser, naturalmente, intensa e tornou-se desde logo motivo de
grande curiosidade e interesse popular. Mormente no seio das classes
trabalhadoras, refletiu-se a atitude extrema da classe ferroviária. Entre os
funcionários da Carris, a greve que explodiu no mesmo dia foi um movimento
quase espontâneo, cuja raiz pode ser facilmente encontrada na repercussão do
gesto ferroviário. Pela manhã, ao partirem os bondes normalmente da estação do
Parque Farroupilha, nada se cogitara. Mas a idéia da greve correu como um
rastilho, ao longo das linhas em tráfego, e empolgou logo um grupo numeroso de
adesistas, que viram chegado o momento duma reivindicação de melhor salário.
Foi estabelecida uma margem de aumento, com o acordo unânime - $40 \%$.

23 “Com a volta dos ferroviários ao trabalho, embora pendente de solução o aumento de salários, cessou a greve na Viação Férrea do Rio Grande do Sul”. Correio do Povo, Porto Alegre, 8/4/1945, p. 20. 
Concordaram na exigência de dois fardamentos. A partir do meio-dia, os simpatizantes da greve foram aumentando - e como tudo sempre se sabe com antecedência em nossa terra, já corria pela cidade o boato de que os bondes iam parar... Houve até quem fizesse "blague":

- Você sabe? Os bondes já estão parando?

- Não diga...?

- Estão, sim! Basta apertar na campainha... ${ }^{24}$

A piada do periódico pode parecer infame, mas a sua descrição do princípio da greve dos motorneiros e trocadores de bonde é digna de maior atenção. Tudo indica que a decisão pela greve ocorrera pela influência da greve dos ferroviários, o que acabou motivando inúmeros trabalhadores da empresa ao longo da manhã. A narrativa parece ser corroborada ainda pelo próprio Sindicato dos Empregados de Carris Urbanos. O presidente, Sr. Arnaldo de Souza, declarara ao Correio do Povo que:

\begin{abstract}
Às 15 horas, mais ou menos, a diretoria do sindicato teve conhecimento do movimento que se preparava entre os que trabalham na Carris Porto-Alegrense. Imediatamente dirigi-me à Delegacia Regional do Trabalho, a fim de pôr o Sr. Norival Paranaguá de Andrade a par do que acontecia, tendo solicitado a intervenção daquele órgão junto à Prefeitura Municipal e à diretoria da Cia. Carris Porto-Alegrense, para conseguir o aumento de salário e pleiteado outras reivindicações dos transviários.

Ouvidos, o prefeito e a diretoria da Carris consideraram justas as pretensões. E, quando ainda os representantes do sindicato se encontravam na Prefeitura, fomos informados de que irrompera o movimento grevista.[...]

Ficará o sindicato aguardando todas as reclamações, encaminhando-as a quem de direito, lamentando que os interessados não tivessem procurado a sua entidade para pleitear seus direitos.
\end{abstract}

Fica a dúvida: quanto de espontaneidade realmente havia nessa greve? Se fosse apenas a influência da greve dos ferroviários, como ela ter-se-ia tornado intensa em cerca de apenas um turno, a ponto de no meio-dia ocorrerem reuniões para decidir as pretensões dos operários? E, ao mesmo tempo, por que o sindicato não notara as movimentações grevistas entre os trabalhadores? Essas duas aparentes contradições nos relatos publicados pelo jornal possibilitam algumas interpretações. A primeira, acerca do grau de organização dos empregados da Carris, fica um pouco mais clara ante da notícia do jornal Folha da Tarde, que fazia oposição direta ao Estado Novo desde a liberação da censura. Interessado em apresentar a greve como fruto da pobreza a que "a ditadura de Vargas condenara o operariado", a cobertura do jornal revela que o "segredo" para a rápida difusão das notícias sobre a greve dos ferroviários e da paralisação da categoria dependeu de um sistema de

\footnotetext{
24 "Declaram-se em greve os ferroviários do Estado e o operariado da Carris". Correio do Povo, Porto Alegre, 6/4/1945, p. 4 e 8.
} 
bilhetes que eram repassados a cada bonde que chegava às estações ${ }^{25}$. Sem dúvida, tal mecanismo de difusão era possível e, de certa forma, ele também conseguiria "driblar" os representantes dos sindicatos. Mas quem os escrevera? O que informavam? Falavam apenas da greve? Indicavam algum nome? Foram apreendidos por alguém dos aparatos de repressão? Todas essas indagações ficam sem resposta, mas certamente ajudam a problematizar um pouco mais como se davam os momentos anteriores do chamamento à greve sem cair na ideia de que "espontaneamente" mais de mil operários resolveram paralisar seu trabalho.

Por sua vez, as reivindicações não indicavam nenhuma estrutura organizativa prévia. De fato, pelo que consta na cobertura do Correio do Povo, os grevistas não tinham uma posição unânime sobre suas demandas. Essas só se formaram como pauta quando o próprio prefeito solicitou que os funcionários apresentassem as suas propostas através de uma comissão de greve. Aparentemente, as reivindicações dos grevistas eram simples de atender, pois se resumiam a uma jornada de trabalho de oito horas por dia, à concessão de dois fardamentos por ano e a um aumento salarial de $40 \%$, todas elas sendo divulgadas por uma comissão dos próprios grevistas. No entanto, a Cia. Carris alegara que a questão salarial era praticamente impossível de ser solucionada e, consequentemente, a jornada de trabalho não poderia ser reduzida para oito horas. Não apenas os gastos seriam muito desproporcionais aos ganhos da empresa, mas também sua sede ficava no Rio de Janeiro, limitando a ação da direção gaúcha. Mesmo a questão dos uniformes não era de fácil solução, pois o diretor da Carris, Dario Gastal, afirmara que a companhia não podia simplesmente "dar" dois uniformes aos seus funcionários. Contando todos os gastos, ele advertia que o custo para a empresa seria de mais de $\operatorname{Cr} \$ 200.000,00$, um preço alto que deveria então ser repassado aos seus próprios funcionários. O prefeito da capital, vendo que a diretoria da Carris não estava disposta a fazer acordos, dirigiu-se então aos trabalhadores em greve e o fez lembrando que o aumento do salário-mínimo estava prometido pelo

\footnotetext{
25 "A fome ronda os lares do povo, como herança trágica de 8 anos de Estado Novo". Diário de Notícias, Porto Alegre, 6/4/1945, p. 8. Apesar disso, a visão do jornal sobre as greves mudara rapidamente ao perceber a efervescência do movimento grevista e sua difusão. Em um editorial escrito no dia seguinte, o jornal clamava que tanto partidários do General Eurico Gaspar Dutra como do Brigadeiro Eduardo Gomes não deveriam permitir a "desordem nos meios operários". Ver: "A quem pode interessar a desordem?" Diário de Notícias, Porto Alegre, 7/4/1945, p. 4.
} 
governo federal já para o Primeiro de Maio, portanto, para daí a menos de um mês. Para a sua surpresa, no entanto, os trabalhadores exigiam o aumento imediato.

As negociações mediadas pelo prefeito de Porto Alegre aumentaram a tensão entre a Carris e os trabalhadores? Difícil dizer ao certo, mas nesse momento, qualquer proposta que não contemplasse o aumento de salário em $40 \%$, a garantia dos uniformes e a redução da jornada de trabalho seria rejeitada pelos grevistas. Sem esse acordo, o que fizeram os operários? Eram já $20 \mathrm{~h} 30$ quando muitos deles "se aglomeraram" na frente da redação do Correio do Povo. Em uma espécie de comício organizado no momento, muitos oradores decidiram falar. O jornal, no entanto, não teve interesse em reproduzir os discursos na folha, mas resumiu-os em alguns pontos: os operários declaravam que a greve era o "único recurso capaz de modificar uma situação insustentável, situação essa criada pela alta alarmante do custo de vida e agravada pelos baixos salários pagos pela Cia. Carris." Outro manifestante, por sua vez, declarou que os trabalhadores da Companhia de Energia Elétrica do Rio Grande do Sul eram solidários aos transviários e defendiam suas reivindicações, mas não entrariam em greve "por uma razão muito simples e humana", ou seja, para garantir o abastecimento de energia elétrica aos hospitais. E diante de outros oradores que ainda teriam falado aos grevistas, a representação dos trabalhadores decidiu que o Correio deveria designar um representante para servir de portador da resposta dos grevistas ao prefeito de Porto Alegre.

Por fim, uma nova reunião foi feita, de onde saiu um ofício que retirava a reivindicação da redução da jornada de trabalho, mas que exigia que os trabalhadores das oficinas da empresa pudessem ter acesso gratuito aos bondes. Mas, o mais interessante exposto no documento era o último parágrafo, onde se afirmava que "os operários da Carris, em greve, repelem qualquer tentativa de serem responsabilizados companheiros isolados pelo movimento de reivindicação iniciado espontaneamente e com o concurso do povo". De certa forma, esse pequeno anúncio traz luz à questão da espontaneidade, pois mesmo que se tome a eclosão da greve como um ato "voluntarista", a necessidade de atingir seus objetivos colocava o movimento na obrigação de defender todos os grevistas, assumindo uma postura coletiva e organizada.

O historiador inglês Alex Callinicos vê em tais situações uma interação de desejos e poderes, na qual a noção de possibilidade se apresenta conforme o objetivo dos agentes 
sociais $^{26}$. No caso específico dos trabalhadores da Carris, o paradigma da greve espontânea parece se apresentar como o principal desejo dos organizadores do movimento. No entanto, a possibilidade de defender tal posição não é tão simples, pois a perseguição individual que faz parte da ação policial repressiva exigia que se saísse em defesa dos companheiros. A partir daí, talvez a retórica da espontaneidade estivesse em risco, mas a organicidade que o movimento adquirira com a luta permitiria a defesa de indivíduos envolvidos para que não sofressem retaliações.

Toda essa situação, que marcou o primeiro dia de greve dos funcionários da Cia. Carris, é bastante significativa. Em primeiro lugar, a intervenção direta do prefeito Antônio Brochado da Rocha na "parede" fora bastante enaltecida pelos jornais. A tentativa de mediar as relações entre os trabalhadores e a companhia dos bondes marca um caminho oficial de lidar com o problema, mas que foge dos canais tradicionais das reivindicações trabalhistas - a dizer, a relação direta entre os sindicatos e a Delegacia Regional do Trabalho. Nesse caso, ao invés de os trabalhadores recorrerem à autoridade, era ela que corria para o pátio da Carris buscando solucionar o problema. Invertendo a lógica anterior, os operários da companhia é que estavam ditando "o ritmo do momento". De todas as greves ocorridas na capital a partir desse dia, essa foi a única em que a intervenção da prefeitura fora tão intensa a ponto de o próprio prefeito sair de seu gabinete para auxiliar nas negociações.

Em segundo lugar, volta-se ao problema da espontaneidade da greve. É difícil aceitar que tal movimentação tão coordenada a ponto de levar à paralisação de tantos operários tenha sido um ato espontâneo, no qual os trabalhadores haviam se levantado apenas pelo drama do custo de vida. Sendo esse um problema comum a todo o período da guerra e que atingia tantas outras categorias, essa explicação diz muito pouco para o historiador hoje. Porém - e esse é um "grande" porém - o próprio ofício feito pela comissão dos representantes dos trabalhadores em greve afirmava que esse movimento de reivindicação havia sido "iniciado espontaneamente". Diante desse impasse, pode-se considerar que esse era um recurso retórico (e talvez até mesmo prático) para enfrentar a perseguição política comum ao Estado Novo. Se o governo soubesse que algum grupo político, como os comunistas, por exemplo, fazia parte da agitação grevista na Carris, a retaliação poderia ser

${ }^{26}$ CALLINICOS, Alex. Making history: agency, structure and change in social theory. Boston. Brill Leiden, 2004, p. 149-150. 
violenta. Esse temor existia entre os próprios operários paralisados. Portanto, afirmar que a greve surgira espontaneamente das condições de vida desses trabalhadores pode não ser real, mas ajuda a revelar uma realidade daquele momento - que era o receio de que a repressão policial atingisse violentamente os organizadores do movimento.

Mas então, como terminou a greve dos funcionários da Carris? O prefeito de Porto Alegre assumiu nas negociações um papel bastante ativo - ora considerando legítima a greve, ora pensando em solucionar o problema o mais rápido possível. Depois da assembleia, concedeu uma entrevista à imprensa em que afirmava que os bondes seriam postos em circulação rapidamente e que os grevistas não sofreriam nenhuma hostilidade ${ }^{27}$. E, de fato, a greve terminou em 24 horas, com as reivindicações dos operários sendo plenamente atendidas. De manhã, a comissão dos grevistas foi até o jornal Folha da Tarde, onde se encontrou com o seu diretor, Arlindo Pasqualini. Ao prefeito e ao chefe do DOPS-RS, Darcy Vignoli, Pasqualini propôs encarregar-se da mediação do conflito. A pressão vinda de vários lados fez com que a diretoria da Carris cedesse às pretensões dos operários, mas afirmou que somente poderia confirmar o acordo quando a matriz do Rio de Janeiro se pronunciasse sobre este. No entanto, isso foi suficiente para que a prefeitura tomasse as rédeas da situação e prometesse que os operários seriam atendidos em suas reivindicações, terminando assim a greve ${ }^{28}$. No editorial do dia 7 de abril, o Correio tecia elogios ao prefeito da capital por ter solucionado a greve, elogiando também a mediação dos "companheiros" do jornal Folha da Tarde, pertencente ao mesmo grupo de notícias do Correio do Povo ${ }^{29}$.

Na verdade, as pretensões dos operários foram registradas pelo Correio do Povo em uma nota onde publicava na íntegra o documento que colocara fim à greve, assinalando alguns pontos que eram reivindicados pelos trabalhadores da Cia. Carris:

Com a mediação do jornal Folha da Tarde, representada pelo seu diretor jornalista Arlindo Pasqualini, aceita pela assembléia dos trabalhadores da Cia. Carris Porto Alegrense, pela Prefeitura Municipal e pela Companhia empregadora, ficou resolvido o imediato retorno dos bondes ao tráfego, mediante as seguintes condições:

- Observância rigorosa do preceito legal que garante salário igual para trabalho igual, garantida a fiscalização com o auxílio da reportagem da Folha da Tarde.

- Concessão imediata de passagens gratuitas para os operários empregados nas oficinas e via permanente, para vinda e volta do trabalho;

\footnotetext{
27 "Circularão bondes hoje - afirma o prefeito". Correio do Povo, Porto Alegre, 6/4/1945, p. 8.

28 "Atendidos em suas pretensões, voltaram ao trabalho os empregados da Carris, normalizando-se o tráfego de bondes". Correio do Povo, Porto Alegre, 7/4/1945, p. 8.

29 "Imprensa, administração e povo". Correio do Povo, Porto Alegre, 7/4/1945, p. 4.
} 
- Intangibilidade dos abonos e mais partes em que está dividido o salário atual;

- Dois fardamentos por ano;

- O aumento de $\mathrm{Cr} \$ 150,00$ mensais será dividido em salário-hora, na base de 200 horas mensais, ou seja, Cr\$ 0,75 por hora, mantendo-se o acréscimo de $25 \%$ já assegurado por lei no caso das horas de trabalho extraordinárias.

- O atual comitê continuará funcionando, para prosseguir pleiteando a satisfação plena dos interesses da classe que representam, plenamente reconhecido pela Prefeitura e pela Companhia;

- O presente acordo será regulamentado para os casos especiais e particulares, que porventura surgirem, por uma comissão provisória integrada por um representante indicado pelo comitê, um representante da Prefeitura e um representante da Folha da Tarde, comprometendo-se com a Companhia a acatar e observar na prática as sugestões indicadas pela comissão.

Dessa forma, os trabalhadores pretendem dar uma demonstração viva do seu espírito conciliador e ordeiro, esperando que sua cooperação ao restabelecimento dos transportes coletivos na nossa cidade seja acompanhada pelo mesmo espírito de transigência da parte da Companhia.

Porto Alegre, 6 de Abril de $1945^{30}$.

Ao que tudo indica, o aumento pleiteado foi conseguido ${ }^{31}$. Os dois uniformes por ano e a passagem gratuita nos bondes também foram garantidos. Mas os indicativos de fiscalização eram, talvez, as conquistas mais importantes, pois em nenhum momento se colocava o sindicato como responsável por essa fiscalização. De fato, nem o sindicato, nem a Delegacia Regional do Trabalho, nem mesmo o DOPS tinham responsabilidade alguma na fiscalização do cumprimento do acordo estabelecido com a greve. E isso certamente poderia ser considerado uma vitória, já que além de estabelecer as bases para um novo momento da organização política da categoria, tinha ainda a garantia do próprio prefeito de Porto Alegre.

Embora possa parecer um certo exagero afirmar que uma vitória política foi construída sem a participação do sindicato, é importante salientar que em junho de 1943 ocorrera uma intervenção da Delegacia Regional do Trabalho no Sindicato dos Trabalhadores nos Carris Urbanos de Porto Alegre ${ }^{32}$. Mesmo que não se saibam ao certo as razões da intervenção, seus efeitos certamente foram sentidos até os dias daquela greve. Por isso, não

\footnotetext{
${ }^{30}$ Neste documento constam as assinaturas de Antônio Brochado da Rocha, Arlindo Pasqualini, João Pereira de Paula Dias, João Oscar de Oliveira, João Gregório do Nascimento, Oscar Artur Becker, Otacílio Ferreira Pinheiro, Antônio Pereira, Antônio da Silva Andrade, Marcos Silveira e Valdemar Herbstrith. Ver: "Íntegra do documento que pôs fim à greve". Correio do Povo, Porto Alegre, 7/4/1945, p. 5. Exceto os dois primeiros nomes, todos os outros eram de operários que organizaram dias depois o Comitê da União dos Operários da Cia. Carris PortoAlegrense. Ver: "O comitê dos empregados da Carris preocupados em cumprir integralmente o acordo". Correio do Povo, Porto Alegre, 12/4/1945, p. 5.

${ }^{31}$ Ainda que não se saiba ao certo qual o salário dos funcionários, o aumento de $\mathrm{Cr} \$ 150,00$ para o saláriomínimo da época é referente a uma proporção de 39,47\% em relação ao salário de $\mathrm{Cr} \$ 380,00$.

32 "Intervenção no Sindicato dos Carris Urbanos". Correio do Povo, Porto Alegre, 5/6/1943, p. 2.
} 
seria absurdo supor que essa instância representante da categoria ainda estava sob forte vigilância do órgão regional do Ministério do Trabalho.

Porém, o clima de euforia que parece ter tomado os trabalhadores naquelas breves, mas intensas 24 horas de paralisação, gerou também problemas para o seu mediador político principal, o prefeito Antônio Brochado da Rocha. Diante da vitória dos grevistas, a prefeitura deveria empenhar, caso necessário, um empréstimo para cobrir o aumento dos trabalhadores até que a Cia. Carris conseguisse, então, pagar seu corpo de funcionários. No entanto, quando a Companhia acenou com um possível aumento no preço das passagens dos bondes, a situação política tornou-se novamente tensa. Brochado da Rocha enviou um ofício à diretoria da empresa, reproduzido pelo Correio do Povo, afirmando que era um erro o aumento da passagem e reiterando que a prefeitura iria colaborar o máximo possível para que a empresa, que "se encontrava com saldo", não tivesse um prejuízo que a paralisasse completamente $^{33}$. De fato, a situação da Carris em Porto Alegre nos anos seguintes seria bastante tensa em relação à prefeitura, incluindo aí as ameaças de encampação da empresa, concretizadas na administração de Leonel Brizola ${ }^{34}$.

Chama a atenção que, quanto à rápida resolução da greve dos trabalhadores da Carris, o movimento paredista de Porto Alegre não tivera a mesma sorte e ainda se estendeu ao longo de uma semana inteira nas mais diversas categorias. De certa forma, é inevitável pensar que ocorre uma espécie de "efeito dominó" sobre as organizações do movimento operário da época, em que a influência da greve de uma categoria poderia impulsionar a greve de outras. Em menos de uma semana, eram poucos os trabalhadores assalariados que não debatiam se deveriam ou não entrar em greve. Entre aqueles que aderiram ao movimento paredista estavam metalúrgicos, bancários, lixeiros, portuários, tintureiros, marceneiros, industriários, obreiros, entre outros. O maior destaque, no entanto, era dado pela imprensa às duas primeiras categorias.

Os metalúrgicos, por sua vez, organizaram-se visitando as direções das fábricas em que trabalhavam, em uma espécie de comitiva que insuflaria a greve entre membros da categoria. Em alguns casos, o Correio do Povo revela o sucesso da iniciativa, como na Companhia Siderúrgica Rio-Grandense, na qual a diretoria aceitou renegociar os salários dos

\footnotetext{
33 "Não é o aumento geral da passagem de bonde o remédio indicado no momento". Correio do Povo, Porto Alegre, 10/4/1945, p. 20.

${ }^{34}$ Prefeitura de Porto Alegre. História da Carris. Porto Alegre, 1995, p. 32 a 60. 
seus trabalhadores, ou mesmo na empresa Wallig, em que os diretores aceitaram a negociação dos vencimentos através de abonos provisórios aos seus empregados. Em outras, no entanto, como na fábrica de Alberto Bins, foram recebidos pelo chefe do Estado Maior da Brigada Militar, o tenente coronel Valter Barcelos, que declarara estar ali para garantir a segurança dos trabalhadores não integrados no movimento grevista, mas não teria deixado a comissão de grevistas chegar à fábrica. Sem dúvida a intimidação surtira efeito, pois os 160 operários da firma continuaram trabalhando ${ }^{35}$. Tal iniciativa, por sua vez, foi explicada pelo próprio Alberto Bins que não aceitara o pedido de aumento de salário "porque este era feito por uma comissão de operários escolhidos entre elementos grevistas". Segundo ele, o apelo "deveria ter partido de comissões designadas pelos sindicatos de classe e não por elementos estranhos às direções dessas entidades". Em tempos de guerra, quando o empresariado valorizava ao extremo a importância da disciplina dos "soldados-operários", o exemplo de Alberto Bins revela o choque entre a exigência do patronato e a realidade dos trabalhadores.

Mas seriam realmente os grevistas elementos "estranhos" às direções sindicais? A declaração de Alberto Bins mostra exatamente um dos principais problemas que surgiram em grande parte das greves do período: a organização por meio de comitês de fábrica, por fora dos sindicatos de classe. Porém, isso não quer dizer que tais trabalhadores fossem estranhos à entidade representativa. No dia 8 de abril, o Sindicato dos Trabalhadores da Indústria Metalúrgica, Mecânica e de Materiais Elétricos de Porto Alegre comprou um espaço no jornal Correio do Povo e outro no Diário de Notícias para anunciar que garantiriam a negociação salarial. Além disso, destaca-se também uma assembleia realizada no dia 26 de abril de 1945, no sindicato da categoria, para debater a proposta de aumento salarial conseguida com as greves ${ }^{36}$. Numa reunião acalorada e com muitos participantes, estavam presentes também o Delegado Regional do Trabalho, Norival Paranágua de Andrade e um representante da Delegacia de Ordem Política e Social. Revela-se, segundo a ata, que alguns dos membros da comissão grevista estavam integrados no sindicato, como o caso de José Cézar de Mesquita, que havia sido eleito em 1944 para a direção da entidade, mas que ainda

\footnotetext{
35 "Generaliza-se a parede a diversas classes trabalhistas". Correio do Povo, Porto Alegre, 7/4/1945, p. 8.

${ }^{36}$ As informações acerca da assembleia foram retiradas da Ata no 18 do Sindicato dos Trabalhadores nas Indústrias Metalúrgicas, Mecânicas e de Material Elétrico, de 4 de agosto de 1942. Livro de atas do Sindicato dos Metalúrgicos de Porto Alegre, p. 30-32.
} 
não assumira o cargo. A figura de Mesquita revela que esse afastamento total dos sindicatos por parte das comissões não os tornava elementos externos à classe e, portanto, poderiam ser reconhecidos pelos trabalhadores.

Além disso, a assembleia fora reveladora acerca da repressão policial e da intolerância patronal, que contraria a ideia de "greves pacíficas", vistas sob o olhar paternalista das autoridades. Um dos operários, Henrique Venâncio Dionísio, funcionário da companhia Cipriano Micheleto \& Irmão, pediu que fosse lavrado na ata um mote de protesto, pois o irmão do dono da firma usara de "coação juntamente com os policiais para que os operários pegassem no serviço". O representante do DOPS, por sua vez, pedira para desconsiderar tal afirmação, pois "desconhecia qualquer ordem da chefia de polícia de se coagir os operários e os trabalhadores". No entanto, mesmo que não houvesse uma ordem escrita, tal condição não era de todo inviável, tendo em vista o caso de Alberto Bins e a defesa feita pela Brigada Militar.

Henrique Dionísio, por sua vez, talvez visando não ser identificado com nenhum grupo político, ainda falou "que na greve não houve interferência de políticos e tinham sido levados àquele ato unicamente por causa da aflitiva situação que os trabalhadores atravessam no momento". Declarando a greve "apolítica" e mencionando a condição dos operários da fábrica, o orador ainda afirmara que "os trabalhadores daquela firma estavam com Getúlio Vargas", criticando aqueles que chamavam Vargas de "ditador". Segundo suas palavras, "Ditador, quem dera fosse um ditador, porque se o fosse estamos certos que ele responsabilizaria os verdadeiros responsáveis pela aflitiva situação que atravessam os trabalhadores". Talvez o pronunciamento do operário tenha um certo exagero, mas mesmo que reflita uma opinião pessoal, é feito em um momento em que duas autoridades do governo estavam presentes e, portanto, indicava um certo sentido de coação. Não seria, como visto em outras greves, a repetição da ideia de greves pacíficas e "apolíticas" como uma forma retórica para evitar essa imposição pela força da polícia e demais autoridades? Mas também ele não poderia indicar que, diante da condição de "soldado-operário" que a guerra impôs, era justo exigir o cumprimento de seus direitos e melhores salários? Em 
outras palavras, não está presente uma ambiguidade que coloca essa suposta deferência como uma forma de se defender dos abusos que o contexto da guerra produzira ${ }^{37}$

A outra greve que ganhou destaque nas páginas dos jornais de Porto Alegre, a greve dos bancários, também fora marcada por intensos debates e pela atenção especial do DOPS. Os grevistas formaram um movimento de centenas de militantes, todos eles saindo na metade do expediente das empresas de crédito em que trabalhavam. No entanto, o capitão Darci Vignolli, chefe do DOPS, determinara que a Guarda Civil passasse a guarnecer a frente dos estabelecimentos atingidos pelo movimento grevista. O presidente do Sindicato dos Bancários, Carlos Ferreira de Azevedo, convocara uma reunião de emergência com os diretores dos principais bancos para estudar as medidas que os grevistas exigiam. Assim como outros movimentos grevistas de abril de 1945 em Porto Alegre, o dos bancários também parece ter ocorrido à revelia do seu sindicato ${ }^{38}$.

Porém, as suas reivindicações eram diferenciadas em relação às de outras categorias, que tinham apenas no aumento de salários o seu eixo de mobilização. Das sete exigências publicadas pelo Correio do Povo, três delas referiam-se aos vencimentos dos trabalhadores (aumento dos salários, abonos familiares, gratificações mínimas). As outras quatro tratavam da organização de quadros de trabalho, da reivindicação de "sábado inglês"39 para todos, do retorno imediato de funcionários mandados para o interior por "castigo" e da garantia de não haver retaliação aos grevistas. De fato, tais preocupações são interessantes para avaliar os próprios pontos de mobilização da greve e indicam um grau de organização diferenciado ${ }^{40}$.

Outros elementos indicam quão organizados estavam os bancários. A sua greve, assim como a dos ferroviários, também se estendeu em âmbito estadual. Além disso, no dia seguinte ao em que ela fora declarada, os grevistas fizeram uma comunicação pela imprensa

\footnotetext{
${ }^{37}$ Um ponto interessante nessa discussão é que Henrique Dionísio Venâncio é lembrado como antiga liderança operária por Alexandre Fortes. Mesmo que sua retórica seja voltada para uma suposta despolitização do movimento, não se pode esquecer que ele já havia sido presidente do Sindicato dos Metalúrgicos de Porto Alegre. Ver: FORTES, Alexandre. Nós do quarto distrito..., p. 340.

${ }^{38}$ "Estende-se a classe bancária ao movimento grevista". Correio do Povo, Porto Alegre, 7/4/1945, p. 5.

${ }^{39} \mathrm{O}$ "sábado inglês" se refere à jornada de trabalho inglesa; nesse dia ela ficava restrita à metade das horas da jornada integral.

${ }^{40}$ Quanto a essa questão dos comerciários, apresentei recentemente a comunicação "As dificuldades da luta sindical em Porto Alegre durante a Segunda Guerra Mundial" nas V Jornadas Regionais do GT Mundos do Trabalho da ANPUH-RS: Trabalho, Justiça e Direitos no Brasil. Os anais do evento serão publicados na revista Aedos, do corpo discente do Programa de Pós-Graduação em História da Universidade Federal do Rio Grande do Sul.
} 
afirmando que os seus companheiros deveriam se precaver contra "informações oriundas de fontes que não merecem crédito" ${ }^{41}$. No dia 11 de abril a paralisação terminou com uma grande vitória para os bancários: o documento que afirmava suas exigências aos bancos foi aceito in totum pelos empregadores, que talvez estivessem temendo o rápido grau de disseminação da greve por várias cidades do Rio Grande do Sul ${ }^{42}$. Exemplar pela organização da categoria, demonstrada pela imprensa local, lamenta-se no entanto que não se conheça ainda uma documentação mais extensa sobre essa greve.

As outras atividades grevistas da cidade não receberam cobertura tão extensa da imprensa, mas através das poucas informações observa-se que tiveram diferentes apreciações. Na fábrica da Souza Cruz, os operários paredistas entraram em confronto com os chamados "fura-greves" e chegaram a ser censurados pelo Delegado Regional do Trabalho (segundo os operários, havia "descaso às leis trabalhistas na fábrica"); os motoristas de ônibus exigiram uma pauta semelhante à dos transviários ${ }^{43}$; operários da indústria do sabão exigiam um aumento de $40 \%$ nos seus vencimentos, assim como os 800 operários da Cervejaria Continental, que também exigiram mais uma hora e meia de almoço; os lixeiros entraram em greve lançando mão de frases secretas transmitidas entre eles; na fábrica AutoRubber a direção se recusou a negociar, afirmando que a greve fora organizada por grupos "estranhos à classe"; na construção civil os operários grevistas acabaram recorrendo ao sindicato para mediar suas já tensas relações com o chefe da polícia política, Darci Vignolli; os portuários desejavam voltar a ser mensalistas, exigindo aumentos salariais e mesmo a redução de sua exaustiva jornada de trabalho, que chegava até 16 horas diárias em certos $\operatorname{casos}^{44}$.

O caso dos portuários revela ainda outros problemas, pois os estivadores se solidarizaram aos seus colegas, mas não entraram em greve. No entanto, eles aproveitaram o momento para fazer um manifesto em que reivindicavam: o aumento salarial de $40 \%$, o

\footnotetext{
41 "Prossegue a greve dos bancários". Correio do Povo, Porto Alegre, 8/4/1945, p. 3.

42 "Cessou a greve dos bancários e metalúrgicos". Correio do Povo, Porto Alegre, 12/4/1945, p. 5.

${ }^{43}$ Importante ressaltar aqui que os motoristas de ônibus referidos não eram funcionários da Companhia Carris, que retirou os ônibus das ruas em 1942 diante da escassez de gasolina e somente no final de 1945 começou a restabelecer sua frota automotiva em Porto Alegre.

${ }^{44}$ Ver: "Generaliza-se a parede a diversas classes trabalhistas". Correio do Povo, Porto Alegre, 7/4/1945, p. 8. Ver também: "O surto grevista". Correio do Povo, Porto Alegre, 8/4/1945, p. 4. "As reivindicações das classes trabalhistas". Correio do Povo, Porto Alegre, 11/4/1945, p. 4. "Reduzida a greve a pequenos grupos isolados". Correio do Povo, Porto Alegre, 13/4/1945, p. 3. "Esperada hoje em Santa Maria a solução da greve dos ferroviários". Diário de Notícias, Porto Alegre, 8/4/1945, p. 8.
} 
aumento no preço para a tonelagem do sal, a garantia de transporte do trigo e demais cereais quando ensacados, a exigência de material de proteção, a atribuição sindical de designar contramestres, o acréscimo do pagamento à tonelagem carregada, o acréscimo salarial para horas extras (como finais de semana, feriados e trabalho noturno), o acréscimo salarial para os horários de refeição, a definição do horário de trabalho e a solicitação prévia em finais de semana; uma remuneração extra para casos de "desencalhe", refeições suficientes e de boa qualidade quando os estivadores tivessem de dormir em embarcações. Esse longo manifesto revela a quantidade de problemas e até mesmo as distinções de trabalho que existiam nos diferentes ofícios que o trabalho portuário exigia, como o grau de vigilância e repressão existente. Os guindasteiros grevistas reclamaram ao Correio do Povo sobre represálias que a direção do porto estava promovendo, colocando-os para realizar trabalhos mais perigosos ${ }^{45}$.

\section{AS GREVES E OS SINDICATOS: CONSIDERAÇÕES FINAIS}

Na verdade, ante o que foi designado pela imprensa porto-alegrense como um "surto grevista", algumas considerações podem ser feitas. A primeira delas é que a ideia da greve "espontânea" e "apolítica" provinha dos próprios operários, mas que antes de crer fielmente nas suas palavras, deve-se ter em mente que caracterizar a paralisação de tal forma visava evitar a perseguição policial que ainda se fazia bastante presente durante todo o período, seja nas ruas, seja nas fábricas, seja nas próprias reuniões de sindicato.

Isso pode levar também a concluir sobre outra questão: qual o papel dos sindicatos nesse momento de efervescência política? De todas as greves noticiadas pela imprensa gaúcha, nenhuma indicava a articulação das entidades de classe. Ao contrário, o mais comum era ver que os sindicatos nem sequer desconfiavam das mobilizações grevistas que estavam a ocorrer. Ainda assim, em muitos casos as suas diretorias se propunham a agir na mediação entre os trabalhadores paralisados e a classe patronal. Tal situação gerava uma espécie de contradição sobre o papel dos sindicatos: para articular a greve, não serviam aos

\footnotetext{
${ }^{45}$ Ver: "Diminui a intensidade do surto grevista". Correio do Povo, Porto Alegre, 10/4/1945, p. 6. Para uma avaliação sobre o trabalho portuário e todas suas variações, assim como a militância operária organizada por ele durante o Estado Novo, ver: SILVA, Fernando Teixeira da. op. cit.,capítulos 2 e 3.
} 
interesses de boa parte dos trabalhadores. Por outro lado, para negociar aumentos e lutar dentro de certa institucionalidade, eram a opção mais adequada para muitos deles ${ }^{46}$.

Em alguns casos essa dicotomia parece ficar mais clara. O Sindicato dos Empregados do Comércio de Porto Alegre era uma entidade de classe bastante ativa. Seus diretores faziam parte do conselho consultivo da CAERGS, organizavam pesquisas sobre o custo de vida da categoria e as divulgavam nos jornais. Enfim, a sua atividade política, dentro dos limites da legalidade do Estado Novo, indica uma posição em que podiam fazer reivindicações salariais sem qualquer temor de retaliações por parte da polícia política. Porém, diante das greves, os líderes do sindicato podiam refletir que o distanciamento com boa parte dos trabalhadores, que era comum entre outras categorias, levou à greve e ao enfraquecimento da estrutura política da entidade ${ }^{47}$.

Tudo indica que essa reflexão fosse realmente feita e não apenas pelo Sindicato dos Empregados do Comércio, mas também pelo Sindicato Patronal dos Comerciantes. No dia 12 de abril, representantes das duas entidades de classe se reuniram em assembleia com um único objetivo: negociar os aumentos salariais dos comerciários antes de qualquer movimentação grevista da categoria eclodir. O jornal Correio do Povo descrevia certo momento da assembleia da seguinte forma:

As entidades da classe reivindicadora, medindo a extensão do perigo e os graves inconvenientes que uma parede grevista dos comerciários de todo o Estado pudesse acarretar não só às classes patronais como ainda à boa marcha da vida pública, avocaram a si a solução da questão, propondo entrar em entendimentos com as entidades comerciais, numa tentativa de resolver amigavelmente o impasse $^{48}$.

\footnotetext{
${ }^{46}$ Tal posição é defendida por Hélio da Costa no caso das greves de São Paulo também, mas em seu trabalho evidencia-se uma agitação operária formada por uma relação mais "orgânica" com o PCB que não se pode comparar com a situação de Porto Alegre. Ainda assim, tal avaliação sobre a diferença entre a ação em comissões de fábrica e a ação sindical parece ser extremamente pertinente para o caso dos trabalhadores da capital gaúcha. Ver: COSTA, Hélio da. op. cit., capítulo 1.

${ }^{47}$ Esse enfraquecimento precisa ser devidamente relativizado. Daniel Aarão dos Reis afirma que já em 1944 os comunistas faziam um chamado para ocuparem sindicatos, aproveitando-se daquela conjuntura. Por outro lado, foram muitos os comunistas que participaram das greves por fora dos sindicatos no período. Nesse limiar de tensão política, afirmar que os sindicatos se enfraqueceram pode parecer incorreto; o que parece ter se enfraquecido, de fato, foram as direções sindicais que eram atreladas à estrutura política do Estado Novo, ou que ao menos colaboravam diretamente com instituições como a Delegacia Regional do Trabalho, o Ministério do Trabalho e, é claro, o DOPS. Ver: REIS FILHO, Daniel Aarão. Entre reforma e revolução: a trajetória do Partido Comunista no Brasil entre 1943 e 1964. In: RIDENTI, Marcelo. AARÃO REIS FILHO, Daniel (org.). História do Marxismo no Brasil. Volume 5: Partidos e organizações dos anos 20 aos 60. Campinas. Ed. Unicamp, 2002, p. 73-74.

48 “Terão aumento os empregados no comércio". Correio do Povo, Porto Alegre, 13/4/1945, p. 4.
} 
É difícil saber até que ponto a concepção de "união", tão repetida nos discursos que foram reproduzidos pelo jornal, realmente fora levada à prática. No entanto, a greve realmente foi impedida e o aumento foi obtido. O Sindicato dos Empregados do Comércio, por sua vez, fizera um apelo por intermédio do Correio para mostrar que entendia os reclames de sua categoria e que desejava não apenas o aumento salarial, ou a introdução da chamada "semana inglesa", mas principalmente a "estabilização imediata dos gêneros de primeira necessidade" por parte do governo ${ }^{49}$. De fato, a carta aberta que o sindicato escrevera falava sobre a necessidade de os próprios comerciários denunciarem a majoração abusiva de preços. Dessa forma, a entidade poderia se legitimar tanto pela incorporação da pauta do aumento salarial como também reforçar a sua principal meta durante os anos da guerra, que era debater o alto custo de vida dos trabalhadores. Isso acaba indicando que a ameaça das greves por si só teria sido o principal fator que colocara o sindicato na obrigação de conseguir um acordo com o patronato.

Mas existia então uma função "desmobilizadora" dos sindicatos no período? Isso é questionável e deve ser avaliado conforme cada caso particular. Entretanto, um ofício publicado no Correio do Povo a pedido de sindicalistas cariocas é bastante revelador de como essa relação entre sindicato e governo poderia implicar um potencial refreamento das lutas do movimento operário. O manifesto enaltecia o esforço dos operários na guerra, afirmando que a sua incansável luta teria ajudado a derrubar o fascismo. No entanto, ele fazia um apelo a toda a classe trabalhadora para "não abandonar aquela orientação de ordem e de disciplina" que lhes teria assegurado o título de "soldados da produção". No final do manifesto ainda havia a sugestão de que os trabalhadores recorressem ao Ministério do Trabalho, demonstrando o espírito de colaboração comum à classe ${ }^{50}$. Durante esse período de greves, esse talvez tenha sido o único texto de âmbito nacional produzido pelo movimento operário, ainda que a sua posição fosse totalmente contrária às paralisações.

Por fim, pode-se questionar até que ponto esse movimento de efervescência dos trabalhadores em abril havia sido realmente vitorioso. E por mais questionável que seja essa hipótese, não são apenas os trabalhadores que apresentam indícios de que suas conquistas foram vitoriosas. Os poderes públicos atrelados à estrutura política do Estado Novo

\footnotetext{
49 "Efetiva colaboração dos comerciários". Correio do Povo, Porto Alegre, 14/4/1945, p. 3.

50 "Apelo do operariado carioca aos trabalhadores do Brasil". Correio do Povo, Porto Alegre, 11/4/1945, p. 5.
} 
acabaram percebendo, a partir de abril, que o movimento operário ainda estava em disputa e que o projeto trabalhista de Vargas tinha um alcance restrito na conquista da deferência dos trabalhadores. Algumas autoridades, como Alberto Pasqualini, defenderam a greve, mas entendiam que as reivindicações de aumento salarial eram apenas paliativas e que a solução para a prosperidade do operariado estava no aumento de produção ${ }^{51}$. Outras, como o ministro João Alberto, não aceitavam a existência das greves, por considerar que elas afetavam a vida econômica do país e, é claro, a produção de guerra do Brasil ${ }^{52}$.

Há alguns casos de depoimentos que merecem mais atenção. Um deles é o de um juiz do Ministério do Trabalho, Djalma de Castilho Maya, presidente do Conselho Regional do Trabalho. Considerando as greves injustificáveis, o juiz também as via como ilícitas, pois foram realizadas sem a orientação dos sindicatos classistas. A partir daí, o jurista elabora um longo texto defendendo que os dissídios coletivos fossem resolvidos dentro da Justiça do Trabalho e, para isso, argumenta que são os Tribunais Regionais do Trabalho que devem agir como mediadores das alegadas "crises políticas" que levam às greves. Sobre estas, Maya argumentava ainda que as paralisações feitas "com honestidade em sua origem" têm seu lado "simpático", desde que não sejam contaminadas por "subalternas paixões" e "tendências de ordem política" 53 .

De certa forma, o argumento do juiz do Trabalho era o da defesa da legalidade construída pelo Estado Novo, ou seja, as greves são ilegais e os dissídios só poderiam ser resolvidos com a mediação da Justiça do Trabalho, e isso valia mesmo para as greves mais "simpáticas". Na verdade, toda essa argumentação era praticamente a mesma que o Delegado Regional do Trabalho, Norival Paranaguá de Andrade, havia usado alguns dias antes, afirmando que as greves eram "recursos antissociais" e que os trabalhadores deveriam recorrer a quem efetivamente lhes representava, ou seja, os sindicatos de classe ${ }^{54}$. Certamente existia o receio de que num futuro próximo os sindicatos perdessem força e os movimentos grevistas voltassem à ativa no Brasil, no Rio Grande do Sul e em Porto Alegre. Era, sem dúvida, um receio bastante fundamentado.

\footnotetext{
51 "A lição das greves". Correio do Povo, Porto Alegre, 8/4/1945, p. 4.

${ }^{52} \mathrm{Um}$ detalhe interessante nas declarações do ministro é que ele afirmara a outros ministros e militares presentes que as greves não partem de elementos "das esquerdas", que segundo seu entendimento vinham colaborando com o governo de Vargas. Para mais, ver: "O ministro João Alberto e os movimentos grevistas". Correio do Povo, Porto Alegre, 8/4/1945, p. 20.

53 "Ponto de vista do juiz do Trabalho". Correio do Povo, Porto Alegre, 18/4/1945, p. 8

54 "Fala o delegado do Trabalho sobre o movimento grevista". Correio do Povo, Porto Alegre, 14/4/1945, p. 5.
} 
Se havia realmente um projeto político do Estado Novo que visava à adesão dos trabalhadores, os empresários tinham como contrapartida a garantia de que não seriam ameaçados pelo operariado. O que as greves de abril de 1945 demonstram, por outro lado, é que o projeto político de Vargas de garantir a submissão dos operários tinha limites. Como enfatiza o historiador britânico E. P. Thompson, a lógica do "paternalismo" é "frouxa", já que possui uma especificidade histórica muito restrita. E, principalmente, que é o que interessa neste caso, é que ele é um termo que "tende a apresentar um modelo da ordem social visto de cima" ${ }^{55}$. Isso pode ser dito em face de uma situação em que mesmo os trabalhadores que não se aproximavam do PCB simpatizaram com as paralisações e reivindicações, em muitos casos até mesmo aderindo a elas. Não foram poucos os sindicatos que, a partir desse cenário, passaram a ter de negociar suas posições tanto com os trabalhadores como com as entidades patronais, tudo isso graças ao impacto das manifestações. É a partir das greves de abril que os operários conseguem manter um papel atuante na rearticulação de um movimento sindical mais autônomo, organizado não pelo Estado, mas sim pelos próprios trabalhadores, e essa, sem dúvida, foi uma de suas maiores vitórias no período.

Mas, além disso, é também a demonstração de que o "esforço de guerra" que construiu milhares de "soldados-operários" não foi tomado como um "destino inevitável", e sim como um caminho a ser negociado e disputado, que envolveu a própria concepção que os trabalhadores sustentavam sobre seus deveres como cidadãos. À medida que o desenrolar da Guerra Mundial apontava para a vitória dos Aliados, não seria absurdo pensar que os operários também desejavam sair vitoriosos de suas batalhas no "front" de Porto Alegre.

Recebido em 17/12/2009

Aprovado para publicação em 24/02/2010

\footnotetext{
${ }^{55}$ THOMPSON, Edward. Patrícios e Plebeus. IN: THOMPSON. Costumes em comum: estudos sobre cultura popular tradicional. São Paulo. Ed. Companhia das Letras, 2005, p. 32.
} 